\title{
PREVALENCE AND FACTORS ASSOCIATED WITH DRUG USE IN PREGNANT WOMEN ASSISTED IN PRIMARY CARE
}

\author{
Danielle Satie Kassada ${ }^{1}$, Adriana Inocenti Miasso², Maria Angélica Pagliarini Waidman ${ }^{3}$, Sonia Silva \\ Marcon $^{4}$
}
${ }^{1}$ M.Sc. in Nursing. Professor of the National Union of Private Higher Education Institutions. São Paulo, São Paulo, Brazil. E-mail: danih_kassada@hotmail.com
${ }^{2}$ Ph.D. in Nursing. Professor of the Department of Psychiatric Nursing and Human Sciences, Universdade de São Paulo. São Paulo, São Paulo, Brazil. E-mail: amiasso@eerp.usp.br
${ }^{3}$ In memoriam
${ }^{4}$ Ph.D. in Nursing Philosophy. Professor of Undergraduate and Graduate Nursing Programs of the Universidade Estadual de Maringá. Maringá, Paraná, Brazil. E-mail: soniasilva.marcon@gmail.com

\begin{abstract}
The aim of this study was to identify the prevalence of drug use by pregnant women assisted in primary care; classifying the medications used according to the risk according to the Food and Drug Administration and grouping drugs used according to the Anatomical Therapeutic Classification. A cross-sectional analytical study was developed in Maringá, Paraná. Data were collected between January and July 2012 through semi-structured interviews in households. The sample comprised 394 pregnant women at different gestational ages. Results revealed that $94.67 \%$ of the pregnant women $(2.03 \%)$ used at least one medication without medical prescription and the most used drugs were antianemics, followed by antiemetics and analgesics. Data showed a statistically significant relationship between the use of medicines and marital conditions, trimester of pregnancy, chronic disease, mental illness and orientation of professionals at the Basic Health Units about medicines. It is noteworthy that, given the complexity of the theme, health professionals, especially nurses, should approach the subject in the care of pregnant women.
\end{abstract}

DESCRIPTORS: Cross-sectional studies. Primary health care. Pregnant women. Drug utilization. Women's health.

\section{PREVALÊNCIA E FATORES ASSOCIADOS AO USO DE MEDICAMENTOS POR GESTANTES ATENDIDAS NA ATENÇÃO PRIMÁRIA}

\begin{abstract}
RESUMO: O objetivo do estudo foi identificar a prevalência do uso de medicamentos por gestantes atendidas na atenção primária; classificar os medicamentos utilizados de acordo com o risco segundo a Food and Drug Administration e agrupar os medicamentos utilizados segundo a Anatomical Therapeutic Classification. Trata-se de estudo transversal, analítico, realizado em Maringá, Paraná. Os dados foram coletados no período de janeiro a julho de 2012, por meio de entrevista semiestruturada, nos domicílios. A amostra constou de 394 gestantes em diferentes idades gestacionais. Os resultados revelaram que $94,67 \%$ das gestantes já havia utilizado, pelo menos, um tipo de medicamento durante a gestação atual, e 2,03\% sem prescrição médica. Os medicamentos mais consumidos foram os antianêmicos, seguidos dos antieméticos e analgésicos. Observou-se relação estatisticamente significativa entre uso de medicamentos e situação conjugal, doença crônica, doença mental, trimestre de gestação e orientação de profissionais das Unidades Básicas de Saúde sobre o uso de medicamentos. É notória, pela complexidade do tema, a necessidade que profissionais de saúde, principalmente o enfermeiro, abordem essa problemática na assistência à gestante.
\end{abstract}

DESCRITORES: Estudos transversais. Atenção primária à saúde. Gestantes. Uso de medicamentos. Saúde da mulher.

\section{PREVALENCIA Y FACTORES ASOCIADOS CON EL USO DE DROGAS EN EL EMBARAZO EN ATENCIÓN PRIMARIA}

\begin{abstract}
RESUMEN: El objetivo del estudio fue identificar la prevalencia del consumo de drogas por mujeres embarazadas inscritas en la atención primaria; la clasificación de los medicamentos utilizados en función del riesgo de acuerdo a las drogas Food and Drug Administration y la agrupación usadas de acuerdo con la Clasificación Anatómica Terapéutica. Se trata de un estudio transversal analítico, en Maringá, Paraná que incluyó 394 embarazadas, en el periodo enero-julio de 2012, a través de entrevistas semi-estructuradas en los hogares. Los resultados mostraron que el $94,67 \%$ de las mujeres embarazadas usaron al menos un medicamento $(2,03 \%$ sin receta médica) y los fármacos más utilizados fueron antianémicos, seguido de los antieméticos y analgésicos. Los datos mostraron una relación estadísticamente significativa entre el uso de medicamentos y el estado civil, trimestre de embarazo, enfermedad crónica, enfermedad mental y la orientación de los profesionales de la salud primaria sobre los medicamentos. Es conocido por la complejidad de la cuestión que los profesionales de la salud, especialmente las enfermeras, desarrollar el papel importante de la educación continua y educación para la salud.
\end{abstract}

DESCRIPTORES: Estudios transversales. Atención primaria de salud. Mujeres embarazadas. Utilización de medicamentos. Salud de la mujer. 


\section{INTRODUCTION}

National and international literature reveal that most women take medication during pregnancy, ${ }^{1-2}$ and the increase in this use seems to be directly related to the increase in pregnant women at an older age. These women are more prone to underlying medical conditions that require treatment, and to present acute diseases and unfavorable clinical conditions inherent to pregnancy. ${ }^{3}$

Many medications are considered safe for use during pregnancy, but there are a significant number of drugs whose use is associated with fetal risks. ${ }^{1-4}$ Moreover, the use of medications that are contraindicated and/or do not have studies confirming they can be used safely during pregnancy persists. $^{4}$

The use of medications during pregnancy has been avoided since the accident with thalidomide, when the relationship between the use of this medication and the birth of thousands of children with severe congenital deformities, characterized by a shortening of long bones of the upper and/or lower limbs, with full or partial absence of the hands, feet and/or fingers, was observed. ${ }^{5}$ Since then, a discussion on the mechanisms of control and surveillance of medication use during pregnancy began. On the other hand, pregnancy is currently followed by a series of interventions with drugs; some of which have good evidence and others, which still need studies to support its use, despite being widely disseminated. ${ }^{6}$

Aiming to guide healthcare professionals in the most appropriate therapeutic choice, the US Food and Drug Administration (FDA) classified drugs according to the effects during pregnancy in five risk categories. Medications that, in controlled studies with pregnant women, have not shown risk to the fetus are included in Category A; medications in which the animal studies did not show fetal risk, but have not yet had controlled studies in pregnant women, or those whose animal studies showed risks not yet confirmed in controlled studies in pregnant women are included in Category B. Category C comprises those that still have not been studied in animals or pregnant women; or those whose studies in animals have shown fetal risk but for which there are no studies with pregnant women. Category D includes those with positive evidence of human fetal risk, but that also show potential benefits to the pregnant woman, which could possibly justify its use. Finally, Category $X$ have all medications that are contraindicated during pregnancy, due to studies in animals and pregnant women that reveal clear evidence of fetal risk. In these cases, the risk to the fetus outweighs any possible benefit to the mother. ${ }^{7}$

For the classification of drug groups we used the first level of the Anatomical Therapeutic Classification (ATC), adopted by the World Health Organization and that refers to anatomical and therapeutic groups. The main groups of this classification are: A - digestive and metabolic systems; B - blood and hematopoietic organs; C - cardiovascular system; D - dermatological medications; G - genitourinary system and sexual hormones; $\mathrm{H}$ - systemic hormonal preparations, except sexual hormones and insulin; G - anti-infective medications for systemic use; L - antineoplasical and immunomodulatory agents; $\mathrm{M}$ - musculoskeletal system; $\mathrm{N}$ - nervous system; $\mathrm{P}$ - antiparasitic products, insecticides and repellents; $\mathrm{Q}$ - veterinary use; $\mathrm{R}$ - respiratory system; $\mathrm{S}$ - the sense organs; and $\mathrm{V}$ - various. ${ }^{8}$

Changes in the pharmaceutical market are frequent, which influences the pattern of prescription and self-medication. In most cases, the adverse effects of new products in relation to pregnancy are not known. Thus, it is appropriate to evaluate and know which drugs are consumed during pregnancy because they can cause damage to the fetus, including low weight, malformations and developmental changes. ${ }^{9}$

The use of medications during pregnancy should, therefore, be prescribed with caution, considering the risk/benefit ratio, which should be evaluated discerningly. This is particularly important in the context of primary care, since the vast majority of pregnant women in the country are accompanied by this level of assistance. Given the above, the objectives of this research were to identify the prevalence of drug use in pregnant women assisted in the primary care network of the city of Maringá, state of Paraná; classifying the medications used according to the risk group described by the FDA and grouping them according to the Anatomical Therapeutic Classification (ATC).

\section{MATERIAL AND METHODS}

An analytical cross-sectional study was conducted in Maringá, Paraná, with pregnant women enrolled in Basic Health Units (BHU) for prenatal care. This municipality has 25 BHUs , 66 Family Health Strategy teams and two reference hospitals for childbirth according to the Unified 
Health System, one in the University Hospital of Maringá and another at Maternidade Santa Casa (a philanthropic maternity hospital).

At the time of data collection, 2,704 pregnant women were registered in the Health Manager (software used in municipal primary care). Exclusion criteria were applied to those with gestational age of 42 weeks or more, with duplicate entries in the $\mathrm{BHU}$, and who were not receiving prenatal care through the primary care system, resulting in 2,504 pregnant women.

The size of the study sample was calculated based on the population of pregnant women registered and able to participate in the study $(2,504)$, considering a ratio of $50 \%$ of individuals who could eventually present the characteristic of interest (drug use), an estimation error of $5 \%$, and a $95 \%$ confidence interval (CI), with another $18 \%$ for possible losses, resulting in a sample of 394 pregnant women. This was followed by random stratified sampling, distributing the sample size proportionally among pregnant women enrolled in each BHU. In cases where the woman drawn did not meet the inclusion and exclusion criteria or refused to participate in the study, the next one on the list was considered for the interview automatically, repeating this operation up to three times.

Data were collected between the months of January and July of 2012, through semi-structured interviews conducted in the patients' households. The instrument used for data collection was the Ministry of Health's first prenatal consultation script (only part I - Clinical History).$^{10}$ The dependent variable was the use of medications during pregnancy. The independent variables were age, years of education, marital status, occupation, family income, color, trimester of pregnancy, number of children, planned pregnancy, previous abortion, mental illness, chronic illness, hospitalization dur- ing pregnancy, participation in pregnancy groups, and having a $\mathrm{BHU}$ professional to advise them on the risks of drug use in pregnancy.

For the classification of medication groups, we used the first level of the Anatomical Therapeutic Classification (ATC), adopted by the World Health Organization. ${ }^{8}$ As for the risk classification, we used the five risk groups defined by the FDA.?

The collected data were entered into an Excel spreadsheet for Windows 2010 and later subjected to statistical analysis using the software Statistical Package for the Social Sciences (SPSS) version 19.0 and the Statistical Analysis System (SAS). The variables of interest were dichotomized regarding the outcome variable (drug use - yes or no), performing a descriptive analysis of the data, which are presented as absolute and relative frequency tables. To verify the association of the variables under study with the outcome of interest and its measure of association, multivariate logistic regression analysis was conducted. For all analyses, a confidence interval of $95 \%$ and a $5 \%$ significance level were considered.

The interviewees signed a Free and Informed Consent Form, according to Resolution no. 196/96, which regulates research involving human subjects. The research project was approved by the Human Research Ethics Committee of the Universidade Estadual de Maringá (Protocol no. 448/2011).

\section{RESULTS}

The mean age of the 394 pregnant women in the study was 26.31 years $( \pm 6.04$, median and mode of 26.0 years), where $61.17 \%$ of them were aged between 19 and 30 years. More than half had between nine and eleven years of education (55.84\%), were married (56.6\%), worked $(56.09 \%)$, had a monthly income of two to three minimum wages $(62.69 \%)$ and were white $(52.03 \%)$ (Table 1$)$.

Table 1 - Number and percentage of drug use by pregnant women in primary care, according to sociodemographic variables. Maringá, Paraná, 2012

\begin{tabular}{|c|c|c|c|c|c|c|c|}
\hline \multirow{3}{*}{$\begin{array}{l}\text { Sociodemographic } \\
\text { variables }\end{array}$} & \multicolumn{7}{|c|}{ Drug use } \\
\hline & \multicolumn{2}{|c|}{ Total } & \multirow{2}{*}{ CI 95\%* } & \multicolumn{2}{|c|}{ Yes } & \multicolumn{2}{|c|}{ No } \\
\hline & $(n=394)$ & $\%$ & & $(n=373)$ & $\%$ & $(n=21)$ & $\%$ \\
\hline \multicolumn{8}{|l|}{ Age } \\
\hline Up to 18 & 41 & 10.41 & $7.4 ; 13.7$ & 37 & 9.39 & 4 & 1.02 \\
\hline 19 to 30 & 241 & 61.17 & $56.6 ; 65.7$ & 226 & 57.36 & 15 & 3.81 \\
\hline 31 to 39 & 106 & 26.90 & $22.3 ; 31.2$ & 104 & 26.39 & 2 & 0.51 \\
\hline \multirow[t]{2}{*}{ Over 40} & 6 & 1.52 & $0.5 ; 3.0$ & 6 & 1.52 & - & - \\
\hline & & & & & & & (Continua \\
\hline
\end{tabular}


Kassada DS, Miasso AI, Waidman MAP, Marcon SS

\begin{tabular}{|c|c|c|c|c|c|c|c|}
\hline \multirow{3}{*}{$\begin{array}{l}\text { Sociodemographic } \\
\text { variables }\end{array}$} & \multicolumn{7}{|c|}{ Drug use } \\
\hline & \multicolumn{2}{|c|}{ Total } & \multirow{2}{*}{ CI 95\%* } & \multicolumn{2}{|c|}{ Yes } & \multicolumn{2}{|c|}{ No } \\
\hline & $(n=394)$ & $\%$ & & $(n=373)$ & $\%$ & $(n=21)$ & $\%$ \\
\hline \multicolumn{8}{|l|}{ Years of education } \\
\hline $\mathrm{Up}$ to 4 & 8 & 2.03 & $0.8 ; 3.6$ & 8 & 2.03 & - & - \\
\hline From 5 to 8 & 120 & 30.46 & $26.1 ; 35.3$ & 116 & 29.44 & 4 & 1.02 \\
\hline From 9 to 11 & 220 & 55.84 & $50.8 ; 60.4$ & 205 & 52.03 & 15 & 3.81 \\
\hline Over 11 & 46 & 11.67 & $8.9 ; 15.0$ & 44 & 11.16 & 2 & 0.51 \\
\hline \multicolumn{8}{|l|}{ Marital status } \\
\hline Single & 84 & 21.32 & $17.1 ; 25.3$ & 76 & 19.29 & 8 & 2.03 \\
\hline Common law & 81 & 20.55 & $16.9 ; 24.8$ & 74 & 18.78 & 7 & 1.77 \\
\hline Married & 223 & 56.60 & $51.4 ; 61.9$ & 219 & 55.58 & 4 & 1.02 \\
\hline Divorced & 4 & 1.02 & $0.2 ; 1.8$ & 2 & 0.51 & 2 & 0.51 \\
\hline Widowed & 2 & 0.51 & $0.1 ; 1.3$ & 2 & 0.51 & - & - \\
\hline \multicolumn{8}{|l|}{ Profession } \\
\hline Employed & 221 & 56.09 & $51.4 ; 61.4$ & 213 & 54.06 & 8 & 2.03 \\
\hline Not employed & 173 & 43.91 & $38.6 ; 48.6$ & 160 & 40.61 & 13 & 3.30 \\
\hline \multicolumn{8}{|l|}{ Family income } \\
\hline No income & 2 & 0.51 & $0.1 ; 1.3$ & 2 & 0.51 & - & - \\
\hline Up to $1 \mathrm{MW} \dagger$ & 32 & 8.12 & $5.6 ; 11.3$ & 28 & 7.10 & 4 & 1.02 \\
\hline 2 to $3 \mathrm{MW}$ & 247 & 62.69 & $57.9 ; 67.4$ & 236 & 59.90 & 11 & 2.79 \\
\hline From 4 to $5 \mathrm{MW}$ & 99 & 25.13 & $21.0 ; 29.0$ & 93 & 23.61 & 6 & 1.52 \\
\hline Over $5 \mathrm{MW}$ & 14 & 3.55 & $2.1 ; 5.6$ & 14 & 3.55 & - & - \\
\hline \multicolumn{8}{|l|}{ Color } \\
\hline White & 205 & 52.03 & $46.8 ; 56.8$ & 192 & 48.73 & 13 & 3.3 \\
\hline Yellow & 22 & 5.58 & $3.6 ; 7.9$ & 22 & 5.58 & - & - \\
\hline Brown & 144 & 36.55 & $32.2 ; 41.7$ & 138 & 35.03 & 6 & 1.52 \\
\hline Black & 23 & 5.84 & $3.3 ; 7.9$ & 21 & 5.33 & 2 & 0.51 \\
\hline
\end{tabular}

In Table 2, it is possible to observe that $42.64 \%$ of the women do not have children. Most did not mention a previous abortion $(84.01 \%)$, mental illness $(87.06 \%)$, chronic disease $(91.12 \%)$, and hospitalization during the current pregnancy $(78.17 \%)$. In addition, more than half of them were in the second trimester of pregnancy (55.84\%), did not plan the pregnancy $(59.9 \%)$, did not attend pregnancy groups in the reference BHU $(62.69 \%)$, and declared they did not receive guidance from any healthcare professional regarding the risks of drug use during pregnancy $(60.15 \%)$.

Table 2 - Number and percentage of drug use by pregnant women in primary care, according to obstetric variables. Maringá, Parana, 2012

\begin{tabular}{|c|c|c|c|c|c|c|c|}
\hline \multirow{3}{*}{ Obstetrics variables } & \multicolumn{7}{|c|}{ Drug use } \\
\hline & \multicolumn{2}{|c|}{ Total } & \multirow{2}{*}{ CI95\%* } & \multicolumn{2}{|c|}{ Yes } & \multicolumn{2}{|c|}{ No } \\
\hline & $(n=394)$ & $\%$ & & $(n=373)$ & $\%$ & $(n=21)$ & $\%$ \\
\hline \multicolumn{8}{|l|}{ Gestational trimester } \\
\hline First & 71 & 18.02 & $14.1 ; 21.7$ & 56 & 14.21 & 15 & 3.81 \\
\hline Second & 220 & 55.84 & $51.2 ; 61.4$ & 214 & 54.32 & 6 & 1.52 \\
\hline Third & 103 & 26.14 & $21.7 ; 30.2$ & 103 & 26.14 & - & - \\
\hline \multicolumn{8}{|l|}{ Number of children } \\
\hline None & 168 & 42.64 & $37.8 ; 47.7$ & 155 & 39.34 & 13 & 3.3 \\
\hline Up to 2 & 185 & 46.95 & $41.9 ; 51.8$ & 179 & 45.43 & 6 & 1.52 \\
\hline From 3 to 4 & 33 & 8.38 & $5.8 ; 11.2$ & 31 & 7.87 & 2 & 0.51 \\
\hline Over 4 & 8 & 2.03 & $0.8 ; 3.6$ & 8 & 2.03 & - & - \\
\hline \multicolumn{8}{|l|}{ Planned pregnancy } \\
\hline Yes & 158 & 40.10 & $35.3 ; 44.7$ & 158 & 40.1 & - & - \\
\hline No & 236 & 59.90 & $55.3 ; 64.7$ & 215 & 54.57 & 21 & 5.33 \\
\hline
\end{tabular}




\begin{tabular}{|c|c|c|c|c|c|c|c|}
\hline \multirow{3}{*}{ Obstetrics variables } & \multicolumn{7}{|c|}{ Drug use } \\
\hline & \multicolumn{2}{|c|}{ Total } & \multirow{2}{*}{ CI95\%* } & \multicolumn{2}{|c|}{ Yes } & \multicolumn{2}{|c|}{ No } \\
\hline & $(\mathrm{n}=394)$ & $\%$ & & $(n=373)$ & $\%$ & $(n=21)$ & $\%$ \\
\hline \multicolumn{8}{|l|}{ Previous abortion } \\
\hline Yes & 63 & 15.99 & $12.5 ; 19.7$ & 58 & 14.72 & 5 & 1.27 \\
\hline No & 331 & 84.01 & $80.3 ; 87.5$ & 315 & 79.95 & 16 & 4.06 \\
\hline \multicolumn{8}{|l|}{ Mental illness } \\
\hline Yes & 51 & 12.94 & $9.7 ; 16.6$ & 49 & 12.43 & 2 & 0.51 \\
\hline No & 343 & 87.06 & $83.4 ; 90.3$ & 324 & 82.24 & 19 & 4.82 \\
\hline \multicolumn{8}{|l|}{ Chronic illness } \\
\hline Yes & 35 & 8.88 & $6.4 ; 12.0$ & 31 & 7.86 & 4 & 1.02 \\
\hline No & 359 & 91.12 & $88.0 ; 93.6$ & 342 & 86.81 & 17 & 4.31 \\
\hline \multicolumn{8}{|c|}{ Hospitalization during pregnancy } \\
\hline Yes & 86 & 21.83 & $18.2 ; 26.1$ & 84 & 21.32 & 2 & 0.51 \\
\hline No & 308 & 78.17 & $73.9 ; 81.8$ & 289 & 73.35 & 19 & 4.82 \\
\hline \multicolumn{8}{|c|}{ Pregnancy group participation } \\
\hline Yes & 147 & 37.31 & $32.5 ; 42.5$ & 137 & 34.77 & 10 & 2.54 \\
\hline No & 247 & 62.69 & $57.5 ; 67.5$ & 236 & 59.90 & 11 & 2.79 \\
\hline \multicolumn{8}{|c|}{ Advice regarding drug use during pregnancy } \\
\hline Yes & 157 & 39.85 & $35.0 ; 44.8$ & 156 & 39.60 & 1 & 0.25 \\
\hline No & 237 & 60.15 & $55.2 ; 65.0$ & 217 & 55.07 & 20 & 5.08 \\
\hline
\end{tabular}

Table 3 shows that the pregnancy trimester is a risk factor for the use of medication, with women in the second trimester of pregnancy having a chance 6.89 times greater to have used medicaments than women who were in the first trimester. Women with partners, without chronic disease, suffering from mental illness and who had received professional guidance on drug use used medications 9.46, 6.27, 6.41, and 9.42 times, respectively.

Table 3 - Multivariate logistic regression analysis for factors associated with drug use by pregnant women assisted in the Basic Health Units of Maringá, Paraná, 2012

\begin{tabular}{lcc}
\hline \multicolumn{1}{c}{ Variables } & CI OR & p-value $\dagger$ \\
\hline Gestational trimester & & \\
$\quad$ First & $2.26 ; 20.99$ & 0.0007 \\
$\quad$ Second & $0.001 ; 999.999$ & 0.9464 \\
$\quad$ Third & $2.75 ; 32.56$ & 0.0004 \\
Marital status & & \\
$\quad$ With a partner & & \\
$\quad$ Without a partner & $1.45 ; 27.13$ & 0.0140 \\
Chronic illness & & \\
$\quad$ Yes & $1.08 ; 37.91$ & 0.0404 \\
$\quad$ No & & \\
Mental illness & & \\
$\quad$ Yes & $0.44 ; 15.35$ & 0.2949 \\
$\quad$ No & & \\
Gestational hospitalization & & \\
$\quad$ Yes & $1.15 ; 77.36$ & 0.0368 \\
$\quad$ No & & \\
Guidance from health professionals & & \\
$\quad$ Yes & & \\
$\quad$ No & & \\
\hline CI OR: Confidence interval of $95 \%$ Odds Ratio; ${ }^{\dagger}$ p-value: $\mathrm{p}$ value for multivariate logistic regression considering the significance \\
level (alpha) $=0.05$
\end{tabular}


Of the 394 pregnant women, most (94.67\%) reported having used at least one medication during pregnancy and only eight $(2.03 \%)$ reported using non-prescription drugs. Among those who admitted to use, there was a total of 1,145 drugs, resulting in an average of 3.36 medications per pregnant woman.

As for therapeutic groups, it was observed that $514(44.89 \%)$ medications were in group B (blood and blood forming organs), and the antianemics (folic acid and ferrous sulphate) were the most consumed. In group A (digestive system), a greater frequency in the use of antiemetics $(10.57 \%)$ was found.

In group C (cardiovascular system), only antihypertensive drugs were found, methyldopa being the most used drug. As for group D (dermatological medicaments), we observed the use of topical antifungal agents such as nystatin, miconazole nitrate and isoconazole. In group $G$ (genito-urinary system and sex hormones), only combined contraceptives and isolated progesterone were found. Regarding group J (general antiinfectives for systemic use), antibiotics stood out, with cephalexin being the most frequent $(3.40 \%)$.

In the therapeutic group $\mathrm{N}$ (nervous system), analgesics (12.05\%) and psychotropic drugs $(1.13 \%)$ prevailed. The products of group P (antiparasitic) represented $2.01 \%$, with metronidazole being the most frequent. As for group R (respiratory system), the use of antihistamines and nasal decongestant (Table 4) was found.

Table 4 - Medications referred to in pregnancy, according to the first level of classification of the Anatomical Therapeutic Chemical (ATC). Maringá, Paraná, 2012

\begin{tabular}{lrr}
\hline \multicolumn{1}{c}{ ATC Classification (level 1) } & n & \% \\
\hline A - Digestive system and metabolism & 305 & 26,64 \\
B - Blood and hematopoietic organs: & 514 & 44,89 \\
C - Cardiovascular system & 8 & 0,70 \\
D - Dermatological medications & 51 & 4,46 \\
G - Genitourinary system and sex hormones & 12 & 1,05 \\
J - General anti-infectives for systemic use & 55 & 4,80 \\
M - Musculoskeletal system & 6 & 0,52 \\
N - Nervous system & 158 & 13,80 \\
P - Antiparasitic products, insecticides and repellents & 23 & 2,01 \\
R - Respiratory system & 13 & 1,13 \\
\hline Total & $\mathbf{1 . 1 4 5 *}$ & $\mathbf{1 0 0 , 0 0}$ \\
\hline
\end{tabular}

*the total number of pregnant women who used medications is greater than the 373 pregnant women because some used more than one medication during pregnancy.

Regarding the risk classification, it was observed that more than half $(52.57 \%)$ of the drugs used were class $\mathrm{A}, 31.52 \%$ were Class $\mathrm{B} ; 13.56 \%$ were Class C; $1.31 \%$ were Class D and $1.04 \%$ were class X.

The class D drugs reported were: carbamazepine, lithium carbonate, paroxetine and ibuprofen, specifically after the thirty-second week of pregnancy, all prescribed by a doctor of the Family Health Strategy, except for lithium carbonate, which was prescribed by a psychiatrist.

As for the class X, 12 women $(1.04 \%)$ declared having used contraceptives during early pregnancy, while still unaware of their condition.

\section{DISCUSSION}

Demographically, the pregnant women studied were characterized as being young (mean age of 26 years). This does not differ from the findings of other studies that analyzed drug use in pregnant women attending prenatal services in primary care, which identified a mean age of 23.4 and 25.75.11-12

A study that analyzed the use of medication by pregnant women assisted in the primary care of another municipality in the state of Paraná observed that $36.6 \%$ of them had between five and eight years of formal education, ${ }^{8}$ which differed from the findings of the current investigation in which more than half $(52.03 \%)$ of the pregnant women had between 9 and 11 years of formal education. This difference in the education of the pregnant women can be related to the differences in living conditions between the two municipalities, defined, for example, by the Human Development Index (HDI) of both cities, for, while Maringá 
is ranked $23^{\text {rd }}$ in the country, Bandeirantes, the municipality of the other study, occupies the $1107^{\text {th }}$ position in Brazil. ${ }^{13}$

The percentage of women who reported use of at least one medication during pregnancy is high $(94.67 \%)$, but close to what has been identified in national surveys with pregnant women in primary care, whose prevalence ranged from $83.8 \%$ to $94.58 \%, 2,8,14$ and also in international research, which ranged from $81.2 \%$ to $85.2 \% .{ }^{1,15}$

The proportion of women who reported not having used any kind of medication during the current pregnancy (the period of this research) was $5.33 \%$, which is close to that found in other studies. ${ }^{8,11}$ It should be noted, however, that $18 \%$ and $55.8 \%$ of them were in the first and second trimester of pregnancy, respectively, and there is a high chance that they would use medication.

According to the data obtained, the most widely used drug was folic acid (72.84\%), differing from other investigations in which ferrous sulfate was the most used drug. ${ }^{11-12}$ This difference is probably related to changes in prenatal care protocol and the encouragement of early identification of pregnant women by the Ministry of Health and also by the Programa Rede Mãe Paranaense (a program for mothers from the state of Paraná) until the 12th week of gestation, a very important period for the use of folic acid, ${ }^{2,8,14}$ given its importance in the formation of the neural tube in the first trimester. $^{14}$

Statistical analysis allowed the identification of the association between the use of medication and the variables trimester of pregnancy, marital status, chronic illness, mental illness and professional guidance of BHU professionals on the risks related to the use of medications during pregnancy.

Regarding the trimester, the analysis showed a positive association between the use of medication and the second trimester, suggesting that women in this pregnancy stage are at higher risk for the event. One can assume that by this period of pregnancy women have had more meetings with health professionals, increasing the possibility of prescription drugs, a fact confirmed in the survey with pregnant women in primary care in Bandeirantes, Paraná. ${ }^{8}$

The existence of a partner was positively associated with the use of medication, even after adjustment among all other variables. This may be related to better family income and consequently to greater purchasing power to obtain drugs. Simi- larly, a multi-center study conducted in Brazil also encountered this type of association. ${ }^{6}$

A positive association between the use of drugs and the presence of mental illness was also observed, probably due to the prescription of continuous use drugs, which are often the only resource available to this population in public health. ${ }^{16}$

In addition to these factors, another item statistically associated with the use of medication was not having a chronic disease. This factor is probably related to medical prescriptions that tend to be less criteria demanding for women who have pre-existing conditions.

Drug use during pregnancy has also been associated with receiving guidance from health professionals, which may be a reflection of the "medication culture" that still permeates the training and work of health professionals and the general population.

The use of antianemics, multivitamins, antiemetics, analgesics, anti-inflammatory and antibiotics were the same as those found in other investigations with pregnant woman. ${ }^{8,11-14}$

As for the risk classification, $85.09 \%$ of the medications used by pregnant women in this research are from classes A and B - without risk to the fetus, and $13.56 \%$ are from class $C$, meaning that the medication is unsafe for use during pregnancy. In a study conducted in Natal, in the state of Rio Grande do Norte, a lower prescription rate of class A and B (69.8\%) medications and a higher rate of class C $(29.3 \%)$ medications were identified. ${ }^{2}$ It should be noted that the frequency of prescription drugs belonging to class D (1.34\%) and X (1.04\%) was higher in the research conducted in Maringá than in Natal, Brazil (0.3\% for Class D and none in class $\mathrm{X}){ }^{2}$

Among class A drugs, antianemics were the most frequent and, fortunately, their use during pregnancy was proven to be safe. The absence of fetal risk for class B drugs, paracetamol for example, has been demonstrated in animals and humans. On the other hand, the use of class $C$ drugs, for example acetylsalicylic acid and dipyrone, has been associated with low birth weight, and may also cause bleeding before and after delivery. ${ }^{11}$

In class $\mathrm{D}$, the use of anticonvulsant, mood stabilizer, non-steroid anti-inflammatory drugs and antidepressants was referred to after the thirty-second week of pregnancy. Although surveys conducted in recent decades point to the use 
of psychotropic drugs, especially antidepressants, during pregnancy being safe, more evidence is needed because there are no conclusive results on the risk of spontaneous abortion after exposure to antidepressants during the first trimester of gestation. ${ }^{17}$ Moreover, an increased risk relative to the use of some antidepressants, such as paroxetine and venlafaxine, has been demonstrated, but not in relation to other selective serotonin reuptake inhibitors (SSRIs) and tricyclic antidepressants. ${ }^{17-18}$

In relation to class D drugs, the use of lithium carbonate and carbamazepine has been associated with congenital malformations. ${ }^{19}$ These drugs have been linked to fetal pulmonary hypertension, low birth weight and coagulation disorders. ${ }^{19}$ However, recent research found no association between the use of these drugs and fetal pulmonary hypertension. ${ }^{20}$

The high prevalence of drug use during pregnancy identified in this study may reflect prenatal care weaknesses in primary care, which include impairment of the continuous assessment of the mother during pregnancy. Continuous assessment of pregnant women will not only identify cases of self-medication, and therefore carry out interdisciplinary educational work ${ }^{21}$ and guidance pursuant to the risks of this practice during pregnancy, but also promote a recommendation and more cautious use of such medication, given the risks to the pregnant woman and the fetus. ${ }^{2,8,11-12,14}$ Such aspects point to the need for specific manuals that guide the conduct of these professionals in order to promote rational use of medications during pregnancy.

\section{CONCLUSIONS}

Through this research, it was observed that a great majority of women reported using medication during pregnancy, and the most used were antianemics, multivitamins, antiemetics and analgesics. Most drugs used $(85.09 \%)$ are considered safe to use during pregnancy. The factors associated with the use of medications during pregnancy were: third trimester of pregnancy, having a partner, not having chronic illness, having mental illness and receiving guidance from health professionals on drug use.

These results could be used to raise awareness of primary care professionals aiming at greater adequacy of the actions developed prenatally, especially regarding the use of medications during pregnancy, thus avoiding complications for both the mother and the fetus.

When considering the complexity of the issue, the need for health professionals, especially nurses, which play an important role in the Family Health Strategy team, to have knowledge of the medications used by women during pregnancy and the possible adverse effects on various gestational periods is notorious. This knowledge can support the planning and implementation of educational measures regarding pregnant women, providing them with greater certainty as to the rational use of drugs during pregnancy.

Finally, it is considered that the use of interviews as a data collection technique may constitute a limitation to the study, given the possibility of measurement bias due to memory failure, confusion or embarrassment of pregnant women to report the use of medications. Additionally, interviews were conducted in different gestational periods, which can cause underestimated values, considering that by the end of pregnancy it is possible that these women have made use of other medications.

\section{REFERENCES}

1. Irvine L, Flynn RW, Libby G, Crombie IK, Evans JM. Drugs dispensed in primary care during pregnancy: a record-linkage analysis in Tayside, Scotland. Drug Saf. 2010 Jul; 33(7):593-604.

2. Guerra GCB, Silva AQB, França LB, Assunção PMC, Cabral RX, Ferreira AAA. Utilização de medicamentos durante a gravidez na cidade de Natal, Rio Grande do Norte, Brasil. Rev Bras Ginecol Obstet. 2008 Jan; 30(1):12-8.

3. Thomas SHL, Yates LM. Prescribing without evidence - pregnancy. Br J Clin Pharmacol. 2012 Oct; 74(4):691-7.

4. Daw JR, Hanley GE, Greyson DL, Morgan SG. Prescription drug use during pregnancy in developed countries: a systematic review. Pharmacoepidemiol Drug Saf. 2011 Sep; 20(9):895-902.

5. Leite SN, Cordeiro BC. A interdisciplinaridade na promoção racional do uso de medicamentos. Cienc Cuid Saude. 2008 Jul-Set;7(3):399-403.

6. Mengue SS, Schenkel EP, Duncan BB, Schmidt MI. Fatores associados ao uso de medicamentos durante a gestação em seis cidades brasileiras. Cad Saúde Pública. 2004 Nov-Dez; 20(6):1602-8.

7. Briggs GG, Freeman RK, Yaffe SJ. Drugs in pregnancy and lactation. $9^{\text {th }}$ ed. Baltimore (US): Williams \& Wilkins; 2011.

8. World Health Organization (WHO) 2013 [página na internet]. The Anatomical Therapeutic Chemical 
Classification System [acesso 2013 Set 23]. Disponível em: http://www.whocc.no/atcddd

9. Melo SCCB, Pelloso SM, Carvalho MDB, Oliveria NLB. Uso de medicamentos por gestantes usuárias do Sistema Único de Saúde. Acta Paul Enferm. 2009 Jan-Fev; 22(1)66-70.

10. Ministério da Saúde (BR). Secretaria de Atenção à Saúde. Departamento de Atenção Básica. Atenção ao pré-natal de baixo risco. Brasília (DF); 2012.

11. Carmo TA, Nitrini SMOO. Prescrições de medicamentos para gestantes: um estudo farmacoepidemiológico. Cad Saúde Pública. 2004 Jul-Ago; 20(4):1004-13.

12. Geib LTC, Vargas Filho EF, Geib D, Mesquita DI, Nunes ML. Prevalência e determinantes maternos do consumo de medicamentos na gestação por classe de risco em mães de nascidos vivos. Cad Saúde Pública. 2007 Out; 23(10):2351-62.

13. IPEADATA. Desenvolvimento humano dos municípios brasileiros 2010 [página na internet]. Índice de Desenvolvimento Humano [acesso 2013 Jan 18]. Disponível em: http://www.pnud.org.br/atlas/ ranking/Ranking-IDHM-Municipios-2010.aspx

14. Brum LFS, Pereira P, Felicetti LL, Silveira LD. Utilização de medicamentos por gestantes usuárias do Sistema Único de Saúde no município de Santa Rosa (RS, Brasil). Ciênc Saúde Coletiva. 2011 JanMaio; 16(5):2435-42.
15. Lupattelli A, Spigset O, Twigg MJ, Zagorodnikova $\mathrm{K}$, Mardby AC, Moretti ME et al. Medication use in pregnancy: a cross-sectional, multinational webbased study. BMJ Open. 2014 Apr; 4(2):1-11.

16. Guedes TG, Moura ERF, Almeida PC. Particularidades do planejamento familiar de mulheres portadoras de transtorno mental. Rev Latino-Am Enfermagem. 2009 Set-Out; 17(5):639-44.

17. Bérard A. Antidepressants and spontaneous abortion. CMAJ. 2011 Aug; 183(11):1031-7.

18. Broy P, Bérard A. Gestacional exposure to antidepressants and the risk of spontaneous abortion: a review. Curr Drug Delivery. 2010 Jan; 7(1):76-92.

19. Harden CL, Meador KJ, Pennell PB, Hauser WA, Gronseth GS, French JA, et al. Management issues for women with epilepsy - Focus on pregnancy (an evidence-based review): II. Teratogenesis and perinatal outcomes. Epilepsia. 2009 May; 50(5):1237-46.

20. Van Marter LJ, Hernandez-DiazS, Werler MM, Louik C, Mitchell AA. Nonsteroidal antiinflammatory drugs in late pregnancy and persistent pulmonary hypertension of the newborn. Pediatrics. 2013 Jan; 131(1):79-87.

21. Zampieri MFM, Gregório VRP, Custódio ZAO, Regis MI, Brasil C. Processo educativo com gestantes e casais grávidos: possibilidade para transformação e reflexão da realidade. Texto Contexto Enferm. 2010 Dez; 15(4):719-27. 